\title{
Analysis of the Cointegration and Causality Relationship to Soybean Imports in Indonesia
}

\author{
Heffi Christya Rahayu ${ }^{1}$, Etty Puji Lestari ${ }^{2}$, \\ Tri Kurniawati Retnaningsih ${ }^{3}$, Anastasia Siti Nurhayati ${ }^{4}$ \\ Faculty Economic, Universitas Pasir Pengaraian, Riau, Indonesia ${ }^{1}$, \\ Faculty Ekonomy, Universitas Terbuka, Indonesia ${ }^{2,3,4}$ \\ \{heffirahayu@upp.ac.id ${ }^{1}$,ettypl@ecampus.ut.ac.id²,nuning@ecampus.ut.ac.id ${ }^{3}$, \\ nurhayati@ecampus.ut.ac.id $\left.{ }^{4}\right\}$
}

\begin{abstract}
Soybeans are a strategic commodity in Indonesia, as soybeans are one of Indonesia's main food crops. Demand for soybeans is very high, therefore Indonesia has to import soybeans. The data used is time series data obtained from the Central Statistics Agency, the Ministry of Agriculture, FAO and the Ministry of Trade. The aim of this analysis is to evaluate the impact of soybean productivity factors, domestic soybean prices, soybean production and soybean harvested area on soybean imports in Indonesia. The data analysis method used in this research is the econometric analysis method with VECM (Vector Error Correction Model). The independent variables in the study used were soybean productivity, soybean production, domestic soybean prices, soybean harvested area, and using the dependent variable volume of soybean imports in Indonesia. The data used in this study are secondary data from time series with a period of 41 years in the period 1980-2020.
\end{abstract}

Keywords: Soybean Productivity; Soybean Production; Domestic Soybean Prices; Soybean Harvested Area; Soybean Import Volume

\section{Introduction}

Soybeans have been growing in demand from year to year. For decades, the difference between soybean production and soybean demand in Indonesia has led to reliance on imports of soybeans (Hasan et al, 2015). Based on the Ministry of Agriculture's 2019 soybean outlook data, the national soybean production for the 2014-2018 period tended to fluctuate and grew an average of $10.97 \%$ per year, but experienced a significant decline in 2016 and 2017 by $10.75 \%$ and $37.33 \%$. A sharp increase is estimated to occur in 2018 of $79.66 \%$, from 2017 production of 538.73 thousand tons to 967.87 thousand tons in 2018. The increase in production is a positive excess of the increase in soybean harvest area in 2018 of $91.23 \%$ or covering an area of 324.58 thousand hectares, from 2017 amounting to 355.80 thousand hectares to 680.38 thousand hectares in 2018. Even though soybean productivity in 2018 decreased by $6.01 \%$ from 2017 amounting to $15.14 \mathrm{ku} /$ ha to $14.23 \mathrm{ku} /$ ha, but did not cause a decrease in production because it was supported by a high increase in harvested area. In the last five years, soybean productivity has tended to be stagnant, slightly increasing by $0.25 \%$ 
per year.

The increase in national soybean production for the 2014-2018 period is a positive effect of a significant increase in harvested area outside Java, namely $27.71 \%$ per year and only $3.08 \%$ per year in Java. This also shows that several areas outside Java such as West Nusa Tenggara, South Sulawesi, Aceh and Lampung have the potential to become soybean centers. As we know so far the main centers of soybeans are still concentrated in the regions of Central Java, East Java and West Java with a contribution to national soybean production of $58.19 \%$.

\section{Literature Review}

\subsection{Soybean Imports}

Soybean imports in Indonesia are influenced by per capita income, the real exchange rate of the rupiah against the US dollar and the price of imported soybeans. According to the theory in Case and Fair (2004: 382), suggests that the level of imports is a function of income. When a country's income increases, people will buy more of everything. This means that if income increases, imports tend to increase. According to the theory in Mankiw (2008: 135), states that the main difference between international transactions and domestic transactions concerns the currency exchange rate. When people in different countries buy and sell from each other, currency exchanges are inevitable. The exchange rate is the price of the currency of a nation denominated in the currency of another country. Exchange rates are differentiated by economists into two: nominal exchange rates and actual cusps.

\subsection{Soybean Productivity}

Soybean productivity is the amount of soybean production per certain area during a production period, measured in tonnes per hectare which is used to manufacture or manufacture materials consumed, for example in making, tofu, tempeh, etc. According to botanists, soybeans are a plant originating from Manchuria and parts of China, and there are wild types of soybeans belonging to the Glycine ussuriensis species. Then it spreads to the tropics and subtropics and breeding is carried out so that various types of superior soybeans are cultivated (Koswara, 2001).

\subsection{Domestic Soybean Prices}

According to Alex S Nitisemito (2007), price is the value of a product or service as determined by a quantity of money where an individual or business is able to release products or services owned by other parties based on this value. And according to Anindita (2004: 68), the price is a sum of money required to satisfy the trade (and probably some goods). For goods accompanied by services, trade may also be performed. Sukirno (2003: 75) said that ombining supply and demand reveals how to assess prices through the interaction between buyers and sellers. The high and low prices dictated by market supply and demand factors can be interpreted this way.

Basically, this theory states that the value of a good is determined by the amount of labor used to produce the goods. The more labor used to produce an item, the more expensive the item is. A country experiences absolute loss or is less efficient in producing a good than other countries. However, there are still advantages from each country, if both of them specialize in 
the production and export of a good that experiences the smallest absolute loss (comparative advantage) and exchanges a portion of its output for other goods Salvatore (1997: 4) with various price levels with the assumption of ceteris paribus. Demand theory analyzes the relationship between price and the quantity of goods requested. If the price of the goods requested increases, the demand for the quantity of an item will decrease, assuming ceteris paribus.

\subsection{Soybean Production}

Soybean production is the sum of the results of the activity of producing soybeans in units of million tons. According to Rahim et al (2007), before the production process is carried out on agricultural land, the process of procurement of agricultural inputs (production facilities) is carried out in the form of the agro-chemical industry (fertilizers and pesticides), the agroautomotive industry (agricultural machinery and equipment), and hatchery and nursery industry. The performance of the Indonesian soybean harvest area from 1980 to 2013 fluctuated but tended to increase with an average increase rate of $0.62 \%$ per year. Indonesia's soybean production centers are located in seven provinces, contributing $87.40 \%$ to national soybean production over the last five years, and 27 other provinces have contributed $12.60 \%$ (Ministry of Agriculture, 2015).

\subsection{Soybean Harvested Area}

Soybean harvested area is the land used for soybean farming as a whole in units of million hectares. Land is defined as the physical environment consisting of climate, relief, soil, water, and vegetation, as well as objects on it, as long as the use of land, including the effects of human activities past and present, is affected. The effect of soybean land area on soybean production in Indonesia is due to the fact that land area is an important input factor in agricultural business. With the expansion of planting land, there will be an increase in agricultural production. The increase in land area coupled with the application of cultivation to the land can increase farmer productivity. So that the more land area farmers use, the soybean production produced by farmers will also increase.

\section{Methods}

This research uses case studies in Indonesia and the data used for this research is data sourced from related sources. This study aims to examine the effect of micro-economic variables, namely soybean productivity, domestic soybean prices, soybean production and soybean harvested area on the volume of soybean imports in Indonesia. The data to be used in this research is secondary annual time series data (time series) from 1980 to 2020 from several related sources. Data analysis techniques or econometric models define statistical relationships between variables in a particular phenomenon.

The analytical methods used in this research are the Co-integration Test and the Vector Error Correction Model (VECM) to see the short-term and long-term relationships in one time series data. In this study, we took the cointegration test and the Vector Error Correction Model (VECM) to examine the short and long term relationships between the microeconomic variables of soybean imports, soybean production, soybean productivity, domestic soybean prices, and soybean harvested area. 


\section{Results and Discussion}

\subsection{Descriptive Statistics}

The results of descriptive statistics are as listed in table 4.1 as follows:

Table 1. The Results of Descriptive Statistics

\begin{tabular}{lccccc}
\hline & IK & HKD & LPK & PDK & PVK \\
\hline Mean & 1293723. & 4588.463 & 857.8180 & 1029.926 & 12.40756 \\
Median & 1220120. & 3766.000 & 678.8500 & 935.1900 & 12.18000 \\
Maximum & 2671914. & 12000.00 & 1665.710 & 1869.710 & 17.52000 \\
Minimum & 72465.00 & 350.0000 & 459.1200 & 521.3900 & 8.380000 \\
Std. Dev. & 727383.3 & 4124.990 & 343.2685 & 351.2167 & 2.343334 \\
Skewness & 0.284142 & 0.569289 & 0.743613 & 0.685996 & 0.282733 \\
Kurtosis & 2.258006 & 1.713873 & 2.163819 & 2.448804 & 2.556934 \\
Jarque-Bera & 1.492232 & 5.040411 & 4.973032 & 3.734725 & 0.881602 \\
Probability & 0.474205 & 0.080443 & 0.083199 & 0.154531 & 0.643521 \\
Sum & 53042629 & 188127.0 & 35170.54 & 42226.98 & 508.7100 \\
Sum Sq. Dev. & $2.12 \mathrm{E}+13$ & $6.81 \mathrm{E}+08$ & 4713331. & 4934128. & 219.6486 \\
Observations & 41 & 41 & 41 & 41 & 41 \\
\hline \multicolumn{5}{c}{} & \multicolumn{5}{c}{}
\end{tabular}

Based on table 4.1, it can be seen that the mean value of soybean import volume (IK) is 1293723, the maximum value is 2671914 , the minimum value is 72465 , and the standard deviation value is 727383.3 . The mean value of domestic soybean price (HKD) is 4588,463 , a maximum of 12000, a minimum value of 350, a value and a standard deviation of 4124.99. The mean value of soybean harvested area (LPK) is 857,818 , the maximum is 1665.71 , the minimum value is 459.12 , the value and standard deviation value is 343,2685 . The mean value of soybean production (PDK) is 1029,926 , the maximum value is 1869,710 , the minimum value is 521.39, and the standard deviation value is 351,2167 . The mean value of soybean productivity (PVK) was 12.40756 , the maximum value was 17.52 , the minimum value was 8.38 , and the standard deviation value was 2.343334 .

\subsection{Unit Root Tests}

From the results of the Augmented Dickey-Fuller (ADF) Unit Root test, it can be seen that the data for $\Delta \mathrm{IK}, \Delta \mathrm{HKD}, \Delta \mathrm{LP}), \Delta \mathrm{PDK}$, and $\Delta \mathrm{PVK}$ are data that do not contain unit roots at the level or are stationary at the first difference level. It can be seen that $p$ value ADF statistics for each variable is smaller than $\alpha=0,05$, this means rejecting the hypothesis $H_{0}$, which means that the unit root does not exist and the data is stationary.

\subsection{The Optimal Lag Length Test}

The results of the optimal lag length test are as listed in table 4.3 as follows:

Table 2. The Results of the Optimal Lag Length Test VAR Lag Order Selection Criteria

\begin{tabular}{cccccccc}
\multicolumn{8}{c}{ VAR Lag Order Selection Criteria } \\
\hline Lag & LogL & LR & FPE & AIC & SC & HQ \\
\hline 0 & -1176.688 & NA & $1.46 \mathrm{e}+23$ & 67.52504 & $67.74723^{*}$ & 67.60174 \\
1 & -1149.899 & $44.39277^{*}$ & $1.34 \mathrm{e}+23$ & 67.42282 & 68.75598 & 67.88303 \\
2 & -1131.087 & 25.80039 & $2.09 \mathrm{e}+23$ & 67.77638 & 70.22050 & 68.62009 \\
\hline
\end{tabular}




\begin{tabular}{ccccccc}
\hline Lag & LogL & LR & FPE & AIC & SC & HQ \\
\hline 3 & -1114.231 & 18.30010 & $4.30 \mathrm{e}+23$ & 68.24179 & 71.79687 & 69.46900 \\
4 & -1073.238 & 32.79443 & $3.04 \mathrm{e}+23$ & 67.32790 & 71.99394 & 68.93862 \\
5 & -1005.576 & 34.79748 & $8.88 \mathrm{e}+22 *$ & $64.89008 *$ & 70.66709 & $66.88431 *$ \\
\hline * indicates lag order selected by the criterion
\end{tabular}

LR : sequential modified LR test statistic (each test at $5 \%$ level)

FPE : Final prediction error

AIC : Akaike information criterion

SC : Schwarz information criterion

HQ : Hannan-Quinn information criterion

Based on Table 4.3, it is known that there are three criterions that determine the optimal lag at lag five, among others, the criterions are the Final Prediction Error (FPE), Akaike Information Criterion (AIC), and Hannan-Quinn Information Criterion (HQ). For sequential modified LR test statistic (LR) determines the optimal lag at lag one, and Schwarz Information Criterion (SC) determines the optimal lag at zero lag. From these results, it can be concluded in this study using lag five, because most of the criterion chose lag five to be used in the study.

\subsection{The Granger Causality Test}

The results of the Granger Causality test is known that those that have a causal relationship are those that have a probability value that is smaller than $\alpha=0,05$, so that $\mathrm{H} 0$ is rejected, which means that a variable will affect other variables.

\subsection{Cointegration Rank Test}

The results of the Cointegration Rank Test are as listed in table 4.5 as follows:

Table 3. The Results of the Cointegration Rank test Unrestricted Cointegration Rank Test (Maximum Eigenvalue)

\begin{tabular}{|c|c|c|c|c|}
\hline Hypothesized & & Max-Eigen & 0.05 & \\
\hline No. of CE(s) & Eigenvalue & Statistic & Critical Value & Prob.*** \\
\hline None ${ }^{*}$ & & & 38.33101 & 0.0000 \\
\hline & & & & 0.0000 \\
\hline & & & & 0.0006 \\
\hline & & & & 0.0017 \\
\hline At most $4 *$ & 0.355391 & 15.80800 & 12.51798 & 0.0136 \\
\hline
\end{tabular}

Max-eigenvalue test indicates 5 cointegrating eqn(s) at the 0.05 level

* denotes rejection of the hypothesis at the 0.05 level

**MacKinnon-Haug-Michelis (1999) p-values

Based on the econometric analysis above, it can be seen that among the five variables in this study, there are five cointegration at the 0.05 significance level. Thus, the results of the cointegration test indicate that among the movements of HKD, IK, LPK, PDK, and PVK have a stability / balance relationship and the similarity of movement in the long term. In other words, in any short-run period, all the variables tend to adjust to one another, to reach their long-run equilibrium. 


\subsection{The Vector Error Correction Model (VECM)}

The VECM estimation results will obtain a short-term and long-term relationship between soybean import volume (IK), domestic soybean price (HKD), soybean harvested area (LPK), soybean production (PDK), and soybean productivity (PVK). In this estimate, soybean import volume (IK) is the dependent variable, while the independent variables are domestic soybean price (HKD), soybean harvested area (LPK), soybean production (PDK), and soybean productivity (PVK). The data analysis technique or the econometric model defines the statistical relationship between the variables using the selected lag which is 5, then the lag in the cointegration test is 4 (minus 1 because the variable is differentiated).

The VECM estimation results are used to analyze the short-term and long-term effects of the dependent variable on the independent variable. The results of the VECM Soybean Import Volume (IK) in the short term are presented in table 4.6 as follows:

Table 4. The results of the VECM Soybean Import Volume (IK) in the short term

\begin{tabular}{ccc}
\hline Variabel & Koefisien & t. statistik \\
\hline CointEq1 & 0.31862 & 0.9177 \\
$\mathrm{D}(\mathrm{IK}(-1))$ & -0.673217 & -1.92459 \\
$\mathrm{D}(\mathrm{IK}(-2))$ & -0.330461 & -0.8941 \\
$\mathrm{D}(\mathrm{IK}(-3))$ & -0.099398 & -0.36105 \\
$\mathrm{D}(\mathrm{IK}(-4))$ & -0.238129 & -0.90674 \\
$\mathrm{D}(\mathrm{HKD}(-1))$ & -13.66676 & -0.09043 \\
$\mathrm{D}(\mathrm{HKD}(-2))$ & 68.9778 & 0.39231 \\
$\mathrm{D}(\mathrm{HKD}(-3))$ & 59.2904 & 0.44017 \\
$\mathrm{D}(\mathrm{HKD}(-4))$ & -438.4538 & -2.3715 \\
$\mathrm{D}(\mathrm{LPK}(-1))$ & -1654.561 & -0.36779 \\
$\mathrm{D}(\mathrm{LPK}(-2))$ & 68.9778 & 0.39231 \\
$\mathrm{D}(\mathrm{LPK}(-3))$ & 59.2904 & 0.44017 \\
$\mathrm{D}(\mathrm{LPK}(-4))$ & -438.4538 & -2.3715 \\
$\mathrm{D}(\mathrm{PDK}(-1))$ & 2368.096 & 0.53598 \\
$\mathrm{D}(\mathrm{PDK}(-2))$ & 3987.323 & 1.00804 \\
$\mathrm{D}(\mathrm{PDK}(-3))$ & 3579.959 & 0.85333 \\
$\mathrm{D}(\mathrm{PDK}(-4))$ & 9208.14 & 1.91301 \\
$\mathrm{D}(\mathrm{PVK}(-1))$ & -488817.8 & -1.19084 \\
$\mathrm{D}(\mathrm{PVK}(-2))$ & -165940.6 & -0.40989 \\
$\mathrm{D}(\mathrm{PVK}(-3))$ & 73245.91 & 0.19096 \\
$\mathrm{D}(\mathrm{PVK}(-4))$ & -434671.8 & -1.01222 \\
$\mathrm{C}$ & 185271.9 & 0.87639 \\
\hline
\end{tabular}

Based on the results presented in Table 4.6, in the short term there are no significant variables. This can be seen from the $t$ statistical value which is smaller than $t$ table, so it can be concluded that in the short term domestic soybean prices (HKD), soybean harvested area (LPK), soybean production (PDK), and soybean productivity (PVK) have no significant effect. to the volume of imports of soybeans (IK).

\subsection{The Variant Decomposition Test}

The results of the Variant Decomposition test is a summary of the results of the FEDV analysis for the volume of soybean imports (IK) from the shocks given by each variable, including itself. The FEDV analysis in Table 4.10 states that in the short term, i.e. year 3 the 
shock to itself results in $78.06827 \%$ fluctuations in the volume of soybean imports, shocks to domestic soybean prices result in $15.48477 \%$ fluctuations in soybean import volume, shocks to soybean harvested area (LPK) resulted in $4.179580 \%$ fluctuation in soybean import volume (IK), shocks to soybean production (PDK) resulted in $1.879516 \%$ fluctuation in soybean import volume (IK), and shocks to soybean productivity (PVK) resulted in $0.387863 \%$ fluctuation in soybean import volume (IK). On the other hand, in the long term, namely in year 10: shocks to itself result in $53.47788 \%$ fluctuations in soybean import volume, shocks to domestic soybean prices result in $20.83482 \%$ fluctuations in soybean import volume, shocks to soybean harvested area (LPK) result in $17.33145 \%$ fluctuation in soybean import volume (IK), shock to soybean production (PDK) resulted in $8.059311 \%$ fluctuation in soybean import volume (IK), and shock to soybean productivity (PVK) resulted in $0.296526 \%$ fluctuation in soybean import volume (IK).

\subsection{Impulse Response}

The results of the Impulse Response test are as listed in the table as follows:

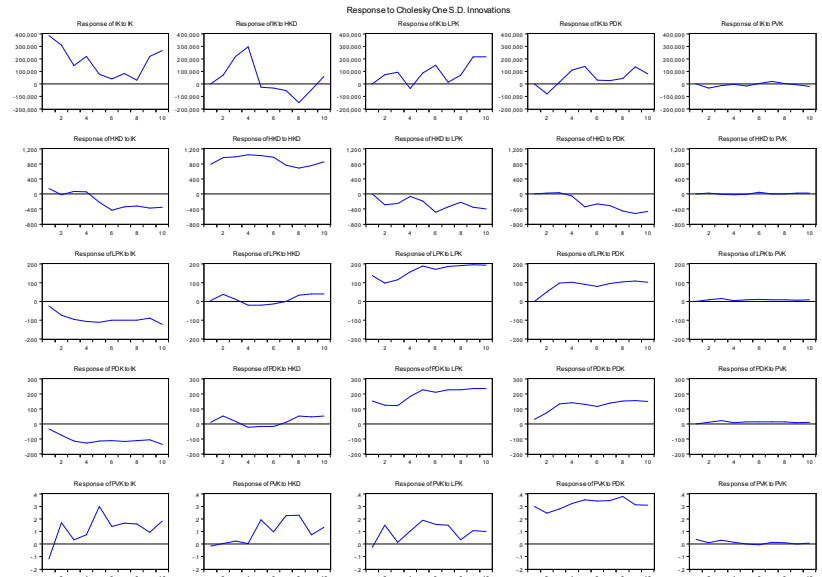

Fig. 1. The Results of the Impulse Response Test

The plot results of the IRF can be seen in Figure 4.1 that there are 25 IRF plots for the next 10 years, which visually explains the response of a variable that arises because of a shock / impulse of 1 standard deviation, both from itself. or other variables.

\section{Conclusions and Recommendations}

\subsection{Conclusions}

Based on the results and discussion, it can be concluded that:

a. Based on the optimal lag length test, the best model is obtained for data on soybean import volume (IK), domestic soybean price (HKD), soybean harvested area (LPK), soybean production (PDK), and soybean productivity (PVK).

b. Based on structural analysis, it can be concluded that the response of each variable to shocks originating from itself is quite significant, because it is fluctuating. And the responses from other variables are generally not significant to soybean productivity shock 
(PVK). On the other hand, the response of soybean productivity (PVK) to the shock of the variable is very significant. Also In general, for future analysis, both in the long term, domestic soybean price (HKD), soybean harvested area (LPK), soybean production (PDK), and soybean productivity (PVK) have a significant effect on the volume of imported soybeans (IK).

\subsection{Recomendations}

It should be noted that the volume of soybean imports (IK) is a policy issued by the Government which is adjusted to the economic conditions that occur in Indonesia, especially with regard to food security. Therefore, it is necessary to conduct an analysis in order to strengthen the food economy, including examining the effects of the domestic soybean price (HKD), soybean harvested area (LPK), soybean production (PDK), and soybean productivity (PVK) on the volume of soybean imports (IK). By testing these four independent variables, the government can predict the relationship between domestic soybean production factors and soybean imports, which in the long run is expected to strengthen food security and food selfsufficiency in Indonesia, especially the food crop sector, the soybean sub-sector. These are economic events that can be used as references by various parties, either by the government or the private sector, to be used in planning and decision making in the future.

\section{References}

[1] Anindita, R. 2004. Pemasaran Hasil Pertanian. Surabaya: Papyrus.

[2] Case, Karl E. dan Ray C. Fair. 2004. Prinsip-Prinsip Ekonomi Makro. Edisi. Kelima, Cetakan Kesatu. Jakarta: PT. Indeks. Chuang YC

[3] Iswandari, D. A. 2018. Analisis Faktor-faktor yang Mempengaruhi Impor Kedelai di Indonesia Tahun 1977 - 2015. Diakses dari https://docplayer.info/87090505-Analisisfaktor-faktor-yang mempengaruhi-impor-kedelai-di-indonesia-tahun.html

[4] Kementerian Perdagangan. 2015. Analisis Outlook Pangan 2015 - 2019. Jakarta: Pusat Kebijakan Perdagangan dalam Negeri, Badan Pengkajian dan Pengembangan Kebijakan Perdagangan.

[5] Kotler, Philip. 1997. Manajemen Pemasaran. Jakarta: Prenhallindo.

[6] Mankiw, N. G. 2008. Pengantar Ekonomi Makro. Jakarta: Salemba Empat.

[7] Maryam. 2002. Evalusai Kesesuaian Lahan Untuk Pemukiman Melalui Pemanfaatan Sistem Informasi Geografis Di Kota Semarang. Skripsi. h. 12

[8] Pusat Data dan Sistem Informasi Pertanian Kementerian Pertanian. 2015. Outlook Komoditas Pertanian Tanaman Pangan. Diakses dari http://epublikasi.setjen.pertanian.go.id/epublikasi/outlook/2015/Tanaman\%20Pangan/O utlook\%20Kedelai\%202015/files/assets/common/downloads/Outlook\%20Kedelai\%20 2015.pdf

[9] Rahim. Abd. Dan Hastuti. DRW. 2007. Ekonomi Pertanian. Jakarta : Penebar Swadaya

[10] Salvatore, Dominick. 2004. Theory and Problem of Micro Economic Theory. 3rd Edition. Alih Bahasa oleh Rudi Sitompul. Jakarta: Penebit Erlangga.

[11] Sukirno, S. 2004. Makroekonomi, Teori Pengantar. Jakarta: PT Raja Grafindo Persada. 